\title{
Analysis of contextual teaching and learning (CTL) in the course of applied physics at the mining engineering department
}

\author{
Fadhilah $^{1}$, Z. Mawardi Effendi and Ridwan \\ Technology of Vocational Education Department of Post Graduate Program \\ Universitas Negeri Padang (UNP) \\ J1. Dr. Hamka Air Tawar Padang 25171, INDONESIA \\ E-mail: dilatambangunp@gmail.com
}

\begin{abstract}
Applied Physics is used to comprehend any other technical engineering studies and as the foundation of technology innovation. As one of the curriculum components in helping the students to be competent in certain skills, it is used to develop intellectual, attitude, interest, skill and creativity. Physics is a course containing materials in form of fact, concept, principle and procedure. The method used in this research was literature studies and observation. The purpose of the research was to analyze whether the seven CTL principles are needed in Applied Physics or it can be simplified. The seven principle used in Indonesia are constructivism, inquiry, questioning, learning community, modelling, reflection and authentic assessment. Having conducting literature studies, especially for Applied Physics, inquiry can be applied along with questioning. Modelling is not the priority because Applied Physics does not need the real model, but only needs an example for Mining Engineering. Meanwhile, reflection has been accommodated in every learning step. Conclusively, constructivism, inquiry and questioning, learning community and authentic assessment are the steps needed during the learning of Applied Physics using CTL approach.
\end{abstract}

\section{Introduction}

CTL approach has been widely used in Physics subject. The Physics subject using CTL through Predict, Observe and Explain method is substantially effective to increase students' high order thinking [1]. CTL approach based on lesson study can increase slow and middle learners' activity, but it does not have contribution for competent students. Nevertheless, there are increasing learning result for all students [2]. The students usually get the low Physics learning result since they cannot synchronize the Physics application in their daily life [3]. Meanwhile, there is no specific research about CTL approach in Applied Physics in colleges or universities. To overcoming the problems related to physics subject learning process in the classroom, there are four principle that should be comprehended by the lecturers; constructivism, context, change, and variability [4]. The constructivism principle says that the students build their own knowledge. The knowledge will be understandable if the materials is along with their daily life (context). It is not easy to change the concept which has been built in the

1 To whom any correspondence should be addressed. 
students' mind although the concept itself is wrong; it is not easy to understand the knowledge which has not been mastered. The knowledge is built based on the context owned by the students. Variability principle says that the students build their knowledge based on their experience so that they have different learning style. It can be seen that the four principles above are along with the CTL approach principle.

The Physics subject is a learning which explains the nature phenomenon in a simple way and it tries to connect between facts found in that phenomenon. The Physics subject should make the students realize that the process is not only about the academic process but also to comprehend the environment. The Physics is not only learning about the facts, the concept, principles and postulate but also to learn how to gain information, to use scientific method, science and technology application. In universities, to learn the Physics is not only to know (what) but also to know cause and effect (why) [5].

Physics is one of the courses which is dislike by the students, in USA (Illinois University) the students comprehend the Physics concept but they cannot solve the problem. They understand the concept explained in the classroom but they find any obstacle in relation to the application [6]. In China, generally the students think the physics course in the universities is complicated to comprehend, they do not understand the teacher's explanation and feel bored to study and are absent to attend the Physics class. It is also found in Malaysia and Slovakia [7] [8] [9].

In Indonesia, the Physics course is provided in theoretical learning. Physics is explained through mathematic formula, diagram, illustration and graphic. The result is the students are not able to comprehend the Physics concept. In the classroom, the students are instructed to solve physics task through mathematic formula without knowing the meaning of the existed formula. So, the Physics symbol becomes something difficult for the students. The lecturers give structural task in the classroom which only discusses the explained lessons/materials. The students usually get low marks in written test but they get high mark in structural task [10] [11]. Physics Education should be able to foster awareness that physics is not just academic activities but rather to understand the environment we are. Learning Physics not only learn the facts, concepts, principles, and laws, but also learn how to learn physics to obtain information, the steps of scientific work, and the application of science and technology. Physics is the basic physical science. It deals with such things as mechanics (force, energy, motion), sound, heat, light, electricity, and atomic structure. In college physics we are concerned not so much with what is so but rather with why it is so. In fact, physics has been described is the science of "why things work" [1].Physics is the basis for engineering science. In college, learning physics does not just know the course (what is) but students are asked to study the causes and consequences (why).

\section{Research methods}

This research was conducted through observing the Physics learning process in the classroom and studying the literature. 


\subsection{Classroom Observation}

The researcher distributed questionnaire to 19 students who follow Applied Physics class. The questionnaire consists of 36 items including the lecturer competent, course materials, teaching and learning process, and student's attitude. The result of observation can be seen in Table 1.

Table 1. Phenomenon Found in Applied Physics Course

\begin{tabular}{llll}
\hline No. & Variable & Das Sain & Das Solen \\
\hline 1. & Learning System & Teacher-centered & Student-centered \\
\hline 2. & $\begin{array}{l}\text { Teaching and } \\
\text { Learning Process }\end{array}$ & Lecture & $\begin{array}{l}\text { Interactive, integrative, } \\
\text { holistic, contextual, and } \\
\text { collaborative }\end{array}$ \\
\hline 3. & Media & Power point & $\begin{array}{l}\text { Multimedia, interactive } \\
\text { media }\end{array}$ \\
\hline 4. & Learning Equipment & Low creativity & High creativity \\
\hline 5. & Student & Lazy, not creative, less & Critical, creative, \\
& & motivation, less & $\begin{array}{l}\text { confidence, highly } \\
\text { motivated. }\end{array}$ \\
& & confidence & $\begin{array}{l}\text { Especially for mining } \\
\text { industry (meaningful } \\
\text { learning) }\end{array}$ \\
\hline 6. & Course application & General & Learning process \\
& example & & \\
\hline 7. & Assesment & Learning result & \\
\hline
\end{tabular}

Based on the result above, CTL approach is appropriate to solve the problem found.

\subsection{Literature Studies}

Literature studies used in this research was done through journal reading and and textbook related to CTL approach and Physics subject. The result is analyzed to know how the seven principle of CTL is applied in Applied Physic. It is assumed that the university students have already grown up. Generally, it can be said that the students has already established mind-set and be able to decide in the classroom. The adult can direct their own selves, having various experiences, and are ready to learn because of their needs, having highly motivation to enter the class and the readiness to study. They need a well-organized, detail and clear program, want to be included in decision making, want to cooperate with the teacher and to assess the purpose needs, to choose the activity and want the proof the learning result [12]. Besides, the students want the teacher as the facilitator, to supervise, to help and to motivate the students when it is needed, they want to know whether the learning is beneficial for them. The student is an individual who has potency to learn by their own selves, from written text, mass media or environment. The lecturer is only to facilitate to create conducive learning atmosphere in order to develop their potency optimally. So the lecturer should create an environmental course system which provides the students to learn from their experience. 
Basically, Physics is a process and a product. Process is a way to gain Physics product in form of fact, concept, principle, theories, and postulate. Physics is a subject to learn nature phenomenon including substance and energy in term of space and time. Physics tries to explain the nature phenomenon. Physics can also be aid as basic science since it relates to phenomenon, behavior, structure of object in nature. Physics consists of material and energy, and any physical things relate to energy transition. Physics is the basic of engineering. As the process and product in teaching and learning process, it is hoped that Physics could go along the learning process which finally produce the product. The products are the students' cognitive, affective and psychometric aspect. Based on Bloom's taxonomy, cognitive aspects consist of; knowledge, comprehension, application, analysis, synthesis and evaluation. It is hoped that the students could be more creative, critic, and reactive toward any problems/tasks given. Affective aspects consist of; emotion, minding-feeling, feeling, eagerness, affection, attitude, assessment system and truth system. It is hoped that the students will have high motivation and eagerness during the learning process while integrating the values in their daily life. Psychometric aspects consist of students' competence or skills in work situations, entrepreneurship, and social life. has a diverse experience, ready to learn due to the needs of himself, entered the program with motivation and readiness to learn is high, like the program a well-organized, detailed and clear, wanted to participate in decisionmaking, would like to cooperate with teachers and assessing the needs of the destination, choose activities and determine the evidence to assess learning. In addition, students prefer that teachers act as unofficial sources to guide, assist, encourage them when necessary, they want to know with certainty that the purpose of learning activities is no benefit to them. Students are individuals who have the potential for self-learning, either from written sources, the mass media or the environment. Lecturer is more to facilitate and create a climate conducive learning so that this potential can develop optimally. Therefore, in the lecture are expected teachers should try to create a system of lectures environment which enables students to learn from the knowledge and experience of each.

\subsection{Contextual Teaching and Learning}

The learning of Applied Physics including the materials in form of facts, concept, principle, and procedure requires the student to gain the meaning of their learning. One of the appropriate approaches is CTL. Contemporary education begins by giving basic knowledge and the application in work situation. The students could be more active since they can synchronize the learning materials with their own experience. In traditional procedure of learning, the process is teacher-centered and focuses on the problem solving which makes the students are passive [13]. CTL system helps the students in looking for the meaning of what they are learning through synchronizing the academic subjects and the context of their daily life; private context, social, and culture [14]. Contextual teaching and learning has been defined differently by experts. Some experts defined contextual learning as the concept to help both teacher and students to synchronize the meaning and the real world situation with the learning materials 
properly. In other words, CTL motivates the students to direct their own learning and to connect between the knowledge and its application with every context found in their life. Besides, constructivism philosophy is said as the reason why the teacher chooses CTL as the alternative ways of teaching and learning approach. In this case, the students are expected to learn through "experiencing" not by "memorizing" the learning materials [15]. Contextual teaching and learning is an instructional system which is based on the philosophy that the students learn when they get the meaning in academic material and then they connect the new information with their prior knowledge [14].

The main factor of learning is the students learn through investigating so that they can study eagerly and pleasantly. The students learn from what they have done (experience). In this case the main role of the teacher is as the facilitator, to extend students' point of view, and to make understandable material. Contextual teaching in Indonesia consists of 7 principles. They are constructivism, inquiry, questioning, learning community, modeling, reflection and authentic assessment [16].

\section{Result and Discussion}

Contextual teaching in Indonesia consists of 7 principles. They are constructivism, inquiry, questioning, learning community, modeling, reflection and authentic assessment. The purpose of the research is to know what principle is needed in Applied Physic.

\subsection{Constructivism.}

Constructivism is a learning philosophy which suggests the students to build their own comprehension about the new idea. There are many written explanations about constructivism in the field of theory and cognition. For instance, Jean Piaget, Eleanor Duckworth, George Hein, and Howard Gardner has deeply explored about constructivism. The students "build" their idea and observation and make it as their "mental-model". This construction is active process but sometimes it happens automatically and unconsciously [4]. The students build the knowledge based on their experience. The teacher directs the students, motivates them and is responsible to give a problem to solve in order to build the students' knowledge [17].

\section{2. .Inquiry and questioning}

Inquiry is one of the strategies to help the students building their knowledge through questioning and answering. Inquiry strategy makes the students active and helps them to find new knowledge [18]. The questions are set and begin with investigation and exploration phase. The questions are very needed in investigation phase, so that inquiry and questioning can be done simultaneously.

\subsection{Learning community}

Learning community really supports the Applied Physics teaching. There are various activity can be done by the students, they can solve the problem, practical learning or project. Several studies show that the learning community provides the students to 
communicate actively and to share knowledge in order to solve the problem. The implementation shows that the learning community is effective to increase the learning, both process and product. The increasing of applied Physics concepts in structural analysis can be reached through: (1) the set of questions for practice in group, (2) giving different but alike questions to every group, (3) giving guidance when the students find difficulties, (4) repetitive drills [19].

\subsection{Modelling and Reflection}

Model given in CTL is not the prototype, but the real model. Nevertheless, the real model is not needed in Applied Physics since it is only the basic subject to support the engineering. It was proved by several researches. Prototyping in education application enriches the concept of physical studies, using the concept with highly comprehension and different communication media (video, photo, text, animation, and feedback test) to help the development and the conceptual representative transformation needed in Physics teaching and learning process [20]. The use of interactive multimedia computer program helps the students to comprehend the applied Physics [21][22][23]. A sample was taken in the field of expertise, such as in Mining Engineering Department which uses the application of Physics in term of mining engineering. Reflection has been accommodated in constructivism, inquiry or learning community. Communication and reflection potentially appear in every point of learning. The learning based on investigation and connecting others step, since it can happen whenever as long as (discussion-action) or after the learning based on inquiry when it looks back (discussion about action ) [18]. The concept of reflective teaching and learning is said as facilitator to develop the teacher's profession. The concept of reflective teaching included every process which supports in general. The thing supporting the factor which influences the learning of students, the choice of activity organization in the classroom, and the use of technique, materials, etc [24].

\subsection{Authentic assessment}

In line with Permenristek DIKTI No. 44 Tahun 2015 about national standard in Indonesia high education Chapter 19: The standard of learning assessment includes some criteria; process, assessing and students' result to gain the graduation. The principle of assessment consists of education principle, authentic, objective, accountable, and transparent which is integrated [25]. Applied Physics learning uses authentic assessment since it emphasizes the process. The assessment includes the cognitive, affective and psychometric aspects.

\section{Conclusion}

From the theoretical analysis above it can be concluded that the learning subjects Applied Physics, the seven principles of the existing CTL can be reduced to four principles, namely constructivism, inquiry, community learning and authentic assessment. Because of Applied Physics is the basis of engineering science courses. The 
principle of questioning and reflection is already included in the inquiry while for modeling, applied physics courses only require examples not real model.

\section{References}

[1] M. Fayakun, P. J. (2015). "Efektifitas Pembelajaran Fisika Menggunakan Model Konteksrual (CTL) dengan Metode" Predict, Observe, Explain terhadap Kemampuan Berpikir Tingkat Tinggi." Jurnal Pendidikan Fisika Indonesia 11 (1) (2015) 49-58: 49-58.

[2] Murtiani, A. F., danRatnaWulan (2012). "Penerapan Pendekatan Contextual Teaching and Learning (CTL) berbasis Lesson Study dalam Meningkatkan Kualitas- Pembelajaran' Fisika di SMP Negeri Kota Padang." Jurnal Penelitian Pembelajaran Fisika U2012): 1-21.

[3] Mundilarto (2005) .Disampaikan pada PPM Terpadu di SMPN 2 MlatiSleman Yogyakarta, $\quad$ tanggal: 20 Agustus 2005 http://staff.uny.ac.id/sites/default/files/130681033/PENDEKATAN\%20KONT EKSTUAL\%2001.pdf 15/11/16

[4] Redish, Edward F 2000. New Models of Physics Instruction Based on Physics Education Research. Journal ERIC CSMEE Paper presented at the Deutschen Physikalischen Gesellschaft (Jena, Germany, March 14, 1996).16p. ERIC ED438184.

[5] Chapman S 1955. How to study physics. Printing of a pamphlet published by Addison-Wesley Publishing Company, Inc. Cambridge 42, Mass. Copyright 1949

[6] Kevin Pitts (C) 2016 The Board of Trustees at the University of Illinois |Department of Physics | College of Engineering | University of Illinois at Urbana-Champaign

[7] Xiaolai Liu,Qun Li and Jiangtao Gao, 2011. A Study on Linking High-school Physics and Perfect Teaching Reformation of College Physics. Canadian Center of Science and Education Vol. 1, No. 1; June 2011 ISSN 1925-4741 EISSN 1925-475X doi:10.5539/hes.v1n1p121

[8] ArsaythambyVeloo, Rahimah Nor \&RozalinaKhalid 2015. Attitude towards Physics and Additional Mathematics Achievement towards Physics Achievement. International Education Studies; Vol. 8, No. 3; 2015 ISSN 19139020 E-ISSN 1913-9039 Published by Canadian Center of Science and Education doi:10.5539/ies.v8n3p35

[9] JurajSlabeycius, Daniel Polčin, Sofia Berezina 2014. Optical Measurements as an Extension of Physics Learning.Procedia - Social and Behavioral Sciences 1411116 - 1120 doi: 10.1016/j.sbspro.2014.05.188

[10] B. Nurdin, S. J., T. Ratelit2013. Pemanfaatan Sumber Belajar Berbasis Contextual Teaching and Learning dalam Upaya Peningkatan Kualitas Pembelajaran Fisika Umum I. JurnalPendidikanFisika Indonesia 9: 18-27.

[11] M. Fayakun, P. J. 2015. Efektifitas Pembelajaran Fisika Menggunakan Model Konteksrual (CTL) dengan Metode Predict, Observe, Explain terhadap Kemampuan Berpikir Tingkat Tinggi. Jurnal Pendidikan Fisika Indonesia 11 
49-58.

[12] Anisah Basleman, Prof.Dr.M Si dan Syamsu Mappa, Prof. Dr (2011). Teori Belajar Orang Dewasa. Remaja Rosdakarya. Bandung. P.18-28

[13] Miller, P. M. 2015. Contextual Learning May be a Better Teaching Model: a case for higher order learning and transfer.ProQuest( Allied Academies International Conference. Academy of Educational Leadership. Proceedings) 2 19.

[14] Johnson, Elaine B. 2014, Contextual Teaching and Learning :Menjadikankegiatanbelajar-mengajarmengasyikkandanbermakna. Penerjemah, IbnuSetiawan; Ida Sitompul, Cet -1. Kaifa. Bandung

[15] Intan Satriani , E. E., Muhammad HandiGunawan (2012). Contextual Teaching and Learning Approach to Teaching Writing . Indonesian Journal of Applied Linguistics Vol. 2 No. 1 July 2012: 10-22.

[16] Evi Suryawati, K. O.,T.SubahanMohdMeerah (2010). The effectiveness of RANGKA contextual teaching and learning on students' problem solving skills and scientific attitude.Procedia Social and Behavioral Sciences 9: 1717-1721.

[17] Nuket Gunduz ,CigdemHursen 2015. Constructivism in Teaching and Learning; Content Analysis Evaluation.Procedia - Social and Behavioral Sciences 191 $526-533$

[18] Margus Pedaste, Mario Mäeots, Leo A. Siiman, Ton de Jong, Siswa A.N. van Riesen, Ellen T. Kamp, Constantinos C. Manoli, Zacharias C. Zacharia, Eleftheria Tsourlidaki2015 Phases of inquiry-based learning: definitions and the inquiry cycle, Educational Research Review, http://dx.doi.org/doi:10.1016/j.edurev.2015.02.003

[19] Jaedun, Amat .2010.,Penerapan Pembelajaran Berbasis Masalah untuk Meningkatkan Kinerja Pembelajaran Fisika . Seminar Nasional HEPI 2010.

[20] Torres M. J., R.M.E.b., Lentz H. A. and Gonzalez C. L., Alternative energies in Physics, a proposal for exploring the teaching of Physics concepts with the solar water heater. Energy Procedia, 2014. 57: p. 975 - 981.

[21] NormahMulop, KhairiyahMohd.Yusof., ZaidatunTasir 2012, A Review on Enhancing the Teaching and Learning of.Procedia - Social and Behavioral Sciences 56: p. $703-712$.

[22] Mohammad Yousef Zadeh ,Secil.Satir 2015, Instruction of applied physics in industrial product design..Procedia - Social and Behavioral Sciences. 182: p. $20-28$.

[23] Krobthong, Thanat2015.,Teaching University Physics by using Interactive Science..Procedia - Social and Behavioral Sciences 197: p. 1811 - 1817.

[24] Camelia Tugui Radulescu. 2012. Systematic reflective enquiry methods in teacher education. Procedia - Social and Behavioral Sciences $33998-1002$

[25] Sutrisno, Prof.Dr.M.Agdan Suyadi,Dr.,M.Pd.I.2015. Desain Kurikulum Perguruan Tinggi mengacu Kerangka KualifikasiNasional Indonesia. PT. Remaja Rosdakarya .Bandung 